\title{
Environmental and stock effects on spawning origins and recruitment of cod Gadus morhua
}

\author{
Gavin A. Begg*, Gudrun Marteinsdottir \\ Marine Research Institute, Skulagata 4, PO Box 1390, 121 Reykjavik, Iceland
}

\begin{abstract}
Recent studies modelling back-calculated birth date distributions of pelagic juvenile (0-group) cod Gadus morhua have indicated differential regional spawning components in waters off the west, north and east coasts of Iceland, in contrast to traditional paradigms of stock structure. The relative proportions of pelagic juvenile cod that were estimated to originate from these regional spawning components were hypothesized to influence recruitment and vary in response to the inflow of Atlantic water from the main spawning grounds off the southwest coast to the main nursery grounds off the north coast. We examine this hypothesis by analyzing annual (1971 to 1998) coastal current data in relation to the total relative abundance, mean total length, and proportions of pelagic juvenile cod that were estimated to originate from the main spawning component off the southwest coast of Iceland. Additional variation in environmental (temperature, salinity, and zooplankton biomass) and spawning stock biomass (SSB) effects were also examined in relation to the 0-group variables and recruitment at Age 3 to enable a detailed analysis of the stock-recruitment relationship. The coastal current index was the most dominant covariate affecting the spawning origins and recruitment of cod in Icelandic waters. The freshwater-induced coastal current provided a predictable transport mechanism for pelagic eggs and larvae derived from the main spawning component off the southwest coast to the main nursery grounds off the north coast. In years when the coastal current were strong, more abundant and larger pelagic juveniles derived from the main spawning component were found on the main nursery grounds, typically resulting in corresponding years of good recruitment. Differentiating the interplay of the physical environment with that of a spawning stock is fundamental to understanding recruitment variability in marine fish stocks.
\end{abstract}

KEY WORDS: Stock-recruitment relationship $\cdot$ Recruitment prediction $\cdot 0$-group $\cdot$ Pelagic juveniles · Spawning diversity $\cdot$ Population dynamics

\section{INTRODUCTION}

One of the central tenets in the population dynamics of exploited marine fish stocks is the fundamental relationship between stock and recruitment (Ricker 1954, Beverton \& Holt 1957, Myers \& Barrowman 1996). Similar to other cod Gadus morhua stocks in the north Atlantic (Hutchings 1996, Cook et al. 1997), the Icelandic cod stock has been severely depleted, with spawning stock biomass (SSB) and recruitment at low levels since the 1980s, and the stock exhibiting a weak

\footnotetext{
*Present address: CRC Reef Research Centre, James Cook University, Townsville, Queensland 4811, Australia.

E-mail: gavin.begg@jcu.edu.au
}

and uncertain stock-recruitment relationship (Schopka 1994, and present Fig. 1). The time interval between strong year-classes has also increased, and belowaverage recruitment occurs more frequently (Marteinsdottir \& Thorarinsson 1998).

Historically, most of the productivity and recruitment of the Icelandic cod stock were assumed to derive from the main spawning component off the southwest coast (Sæmundsson 1924, Jónsson 1982, see present Fig. 2). However, recent studies have indicated that smaller regional spawning components off the west, north, and east coasts may be contributing more significantly to the overall productivity of the stock than was traditionally accepted (Begg \& Marteinsdottir 2000, 2002 in this issue, Marteinsdottir et al. 2000a). During late 


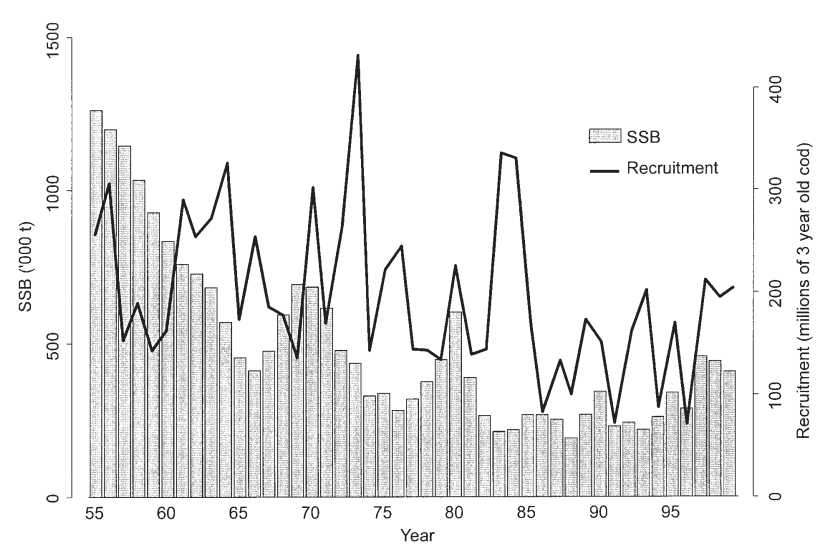

Fig. 1. Gadus morhua. Spawning stock biomass (SSB in thousands of tons) and recruitment (millions of 3 yr old cod) estimated for the Icelandic cod stock, 1955 to 1999 (Anonymous 2000)

March, April, and early May, most of the pelagic eggs and larvae derived from the main spawning component off the southwest coast drift clockwise around the country with the westward flow of the coastal current and the northward Atlantic inflow of the Irminger Current to the main nursery grounds off the north coast (Astthorsson et al. 1994, Begg \& Marteinsdottir 2000) (see Fig. 2). In contrast, back-calculated birth-date distributions of pelagic juvenile cod have indicated later spawning, extending into June, for regional spawning components off the north and east coasts, where eggs and larvae are most probably retained within fjords and inshore waters (Begg \& Marteinsdottir 2000, Marteinsdottir et al. 2000a).

Currently, the Icelandic cod stock is assessed as a single, homogeneous unit (Anonymous 2000), despite the prevalence of regional spawning components (Begg \& Marteinsdottir 2000, 2002 Marteinsdottir et al. 2000a). This is characteristic of most fisheries assessments which model the dynamics of closed populations and assume homogeneous life-history characteristics, even though misleading results can be produced if several closed populations, or a portion of a population, are the components actually modelled (NRC 1994). An inherent level of uncertainty concerning the actual stock structure being modelled generally prevails in stock assessments, but failure to recognise or account for stock diversity can lead to erosion of spawning components (Stephenson 1999). Stock diversity can also create biases in stock-recruitment relationships when there are differential levels of exploitation of the individual spawning components comprising a stock (Hilborn \& Walters 1992). Differentiating the relative contribution, dynamics and sources of variability that affect the productivity of each spawning component is necessary if we are to account for spatially aggregated biases in stock-recruitment relationships.

A recent study by Begg \& Marteinsdottir (2000), based on back-calculated birth-date distributions of pelagic juvenile cod, provided initial estimates of the relative proportions of cod originating from regional spawning components in waters around Iceland. The relative contribution of each spawning component was suggested to vary in response to environmental and stock effects that influence the dispersal and survival of the early life-history stages. A potentially important source of interannual variability in the relative contribution of each spawning component was hypothesized to be related to the strength and timing of the coastal current and Atlantic inflow from the main spawning grounds off the southwest coast to the main nursery grounds off the north coast. Considerable variation in the Atlantic inflow has been demonstrated (Malmberg \& Kristmannsson 1992), and initial studies have examined its influence on recruitment (Ólafsson 1985), but there has been no attempt to rigorously test the dispersal and abundance of pelagic juvenile cod as a function of inflow or coastal current variability.

We examined this hypothesis by analyzing annual (1971 to 1998) coastal current data in relation to the proportions of pelagic juvenile cod that were estimated by Begg \& Marteinsdottir (2000) to originate from the main spawning component off the southwest coast of Iceland. Additional variation in environmental and stock effects were also examined in relation to the estimated spawning origins of pelagic juvenile cod to enable a detailed analysis of the stock-recruitment relationship. The results of our study are placed in the context of spawning stock structure and recruitment prediction to provide an understanding of environmental and stock effects on variable recruitment levels in the Icelandic cod stock.

\section{MATERIALS AND METHODS}

Data on spatial distribution, abundance, and biological characteristics of pelagic juvenile cod were obtained from the annual (1970 to 1998) 0-group fish surveys conducted by the Marine Research Institute (MRI), Iceland. Sampling was conducted using a Harstad pelagic trawl $(18 \times 18 \mathrm{~m}$ opening; $0.5 \times 0.5 \mathrm{~cm}$ codend mesh) at <90 stations between 1970 and 1972 , and $>150$ stations since 1973. Standardised survey methods were used throughout the survey period, with trawls generally made at depths of 20 to $50 \mathrm{~m}$. Acoustic records were used to monitor changes in fish distribution and abundance and to determine sampling frequency. A sample was taken whenever acoustic records changed or approximately every 20 nautical 
miles (nm). The abundance of pelagic juvenile cod at each station was recorded as the number of cod captured per nm towed. Total lengths $(\mathrm{mm})$ of cod were adjusted (based on a measured growth rate of $0.65 \mathrm{~mm}$ $\mathrm{d}^{-1}$ ) to the mean cruise date of the surveys (20 August), enabling a direct comparison of historical data between years (Begg \& Marteinsdottir 2000). The 0-group data were separated into inshore (Regions 1a to 7a) and offshore (Regions $1 \mathrm{~b}$ to $7 \mathrm{~b}$, and 8) statistical regions on the basis of known spawning locations and dispersal patterns of eggs and larvae (Marteinsdottir et al. 2000b) and the $100 \mathrm{~m}$ depth contour (Fig. 2). An additional spatial effect was examined by analysing the data according to those cod collected in waters off northern (Regions 2 to 6) and southern (Regions 1 and 7) Iceland separately, because of hydrographical and ecological differences in their ecosystems (Fig. 2). Horizontal gradients prevail between these waters (corresponding to the above-defined regions), whereby the northern waters are typically colder and more variable than the southern waters (Malmberg \& Kristmannsson 1992).

Annual (1970 to 1998$)$ relative abundance indices for each region $\left(I_{r}\right)$ of pelagic juvenile cod were derived from Begg \& Marteinsdottir (2000) to determine the spatial distribution and dispersal of progeny following spawning (Table 1). These indices were calculated each year $(y)$ according to the following equations:

$$
\begin{aligned}
& X_{r}=\frac{1}{N_{r}} \sum \log _{\mathrm{e}}\left(X_{i}\right) \\
& I_{r}=X_{r} \cdot\left(\frac{N_{r}}{N_{t}}\right) \cdot\left(\frac{G_{r}}{G_{t}}\right) \\
& A_{Y}=\sum I_{r}
\end{aligned}
$$

where in each region $r$ (Regions 1a to 8), $X_{r}=$ logarithmic mean abundance of pelagic juvenile cod, $N_{r}=$ number of stations where catch was $>0, X_{i}=$ number of cod captured per nm towed at Stn $i$ where the catch also was $>0, N_{t}=$ total number of stations, $G_{r}=$ geographic area $\left(\mathrm{km}^{2}\right)$ of the region, and $G_{t}=$ total geographic area of all the regions. For regions where there was no sampling in a given year, the mean index (1970 to 1998) for those regions was used instead. $A_{y}=$ total relative abundance index of pelagic juvenile cod for each year.

Adjusted (20 August) total lengths and estimated spawning distributions of pelagic juvenile cod were also derived from Begg \& Marteinsdottir (2000). The proportion of pelagic juvenile cod estimated to originate from spawnings later than the 99th percentile of the spawning distribution of cod from the main spawning component (Region 1) was assumed to originate from spawning components other than the main spawning component off the southwest coast. Spawning distributions were estimated using incubation
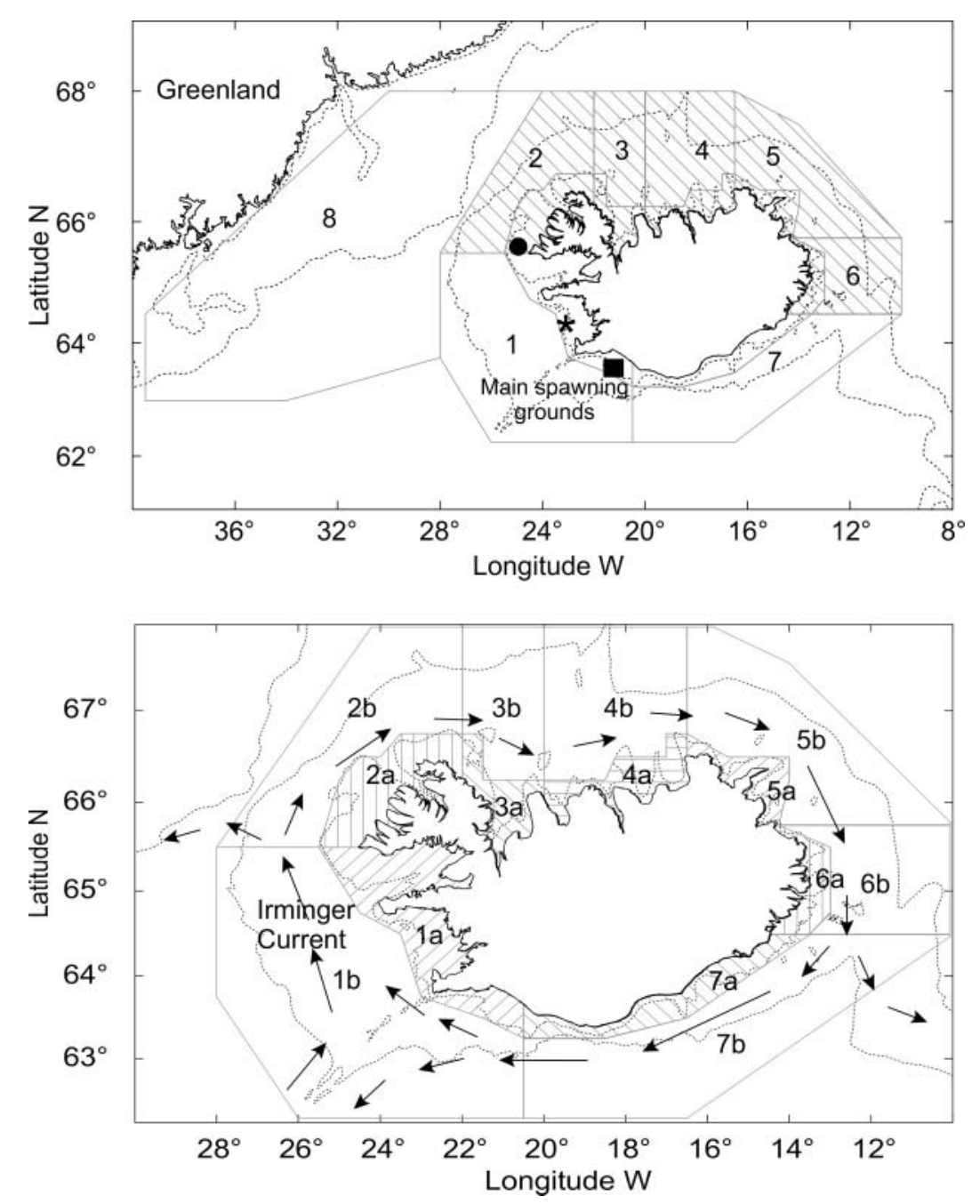

Fig. 2. General ocean circulation patterns (arrows; Malmberg \& Kristmannsson 1992), and inshore (Regions 1a to $7 \mathrm{a}$ ) and offshore (Regions $1 \mathrm{~b}$ to $7 \mathrm{~b}$ and 8 ) regions where pelagic juvenile cod were sampled in Icelandic waters. Shaded regions in the upper graph represent the northern statistical area (Regions 2 to 6); unshaded region represents the southern statistical area (Regions 1 and 7). Annual temperature and salinity data were collected off the west coast ( $*$ in top graph), coastal current data off the northwest coast $(\bullet)$, and zooplankton data off the south, west and northwest coasts $(\boldsymbol{\bullet}, \boldsymbol{*}, \bullet)$. The main spawning grounds are located in Region 1 
periods based on annual estimated daily temperature cycles for waters off the south coast of Iceland that were assumed to be representative of environmental conditions in the main spawning grounds. Further details of the estimation of spawning origins can be found in Begg \& Marteinsdottir (2000).

Data on annual (1971 to 1998) 'environmental' conditions (temperature, salinity, zooplankton biomass, and coastal current index), collected by the MRI each year in spring (May and June) (Anonymous 1999), were examined to determine the effect of these conditions on the spatial distribution and dispersal of pelagic juvenile cod and subsequent recruitment at Age $3 \mathrm{yr}$. Temperature $\left({ }^{\circ} \mathrm{C}\right)$ and salinity data were collected at a depth of $50 \mathrm{~m}$ from 2 fixed survey stations (1971 to 1982 : $64^{\circ} 00^{\prime} \mathrm{N}, 24^{\circ} 00^{\prime} \mathrm{W} ; 1983$ to $1998: 64^{\circ} 20^{\prime} \mathrm{N}$, $23^{\circ} 45^{\prime} \mathrm{W}$ ) near the main spawning grounds off the southwest coast (MRI unpubl. data, and present Fig. 2). Zooplankton data were typically collected at 23 stations along standardized transects off the south, west and northwest coasts at depths of 0 to $50 \mathrm{~m}$ (Gislason unpubl. data, and present Fig. 2). Zooplankton data were averaged across transects, converted to measures of biomass (g dry weight $\mathrm{m}^{-2}$ ) (Astthorsson et al. 1994), and used to provide an indication of annual productivity and food availability to first-feeding larvae, following peak spawning of the main spawning component. Coastal current data were collected from 5 fixed survey stations at depths of 0 to $100 \mathrm{~m}$ along a standardized transect off the northwest coast (Anonymous 1999, and present Fig. 2). This transect intersected the main drift route of pelagic eggs and larvae that were dispersed from the main spawning grounds in the southwest to the main nursery grounds in the north. Data collected along this transect were used to calculate an annual coastal current index $\left(C_{Y}\right)$ based on the thickness of the freshwater layer (m), according to the following equations (Ólafsson 1985):

$$
\begin{aligned}
& F_{x d}=\frac{S_{\mathrm{o}}-S_{x d}}{S_{\mathrm{o}}} \\
& C_{y}=\sum_{d=0}^{100} \frac{\left(F_{x d}+F_{x d}+1\right)\left(Z_{d+1}-Z_{d}\right)}{2}
\end{aligned}
$$

where, in each year $y, F_{x d}=$ fraction of freshwater at Stn $x$ and Depth $d, S_{0}=$ maximum salinity of oceanic

Table 1. Gadus morhua. Relative abundance index of pelagic juvenile cod in each region (Regions 1a to 8), 1970 to 1998. Values

\begin{tabular}{|c|c|c|c|c|c|c|c|c|c|c|c|c|c|c|c|c|}
\hline \multirow{2}{*}{ Year } & & & & & & & \multicolumn{4}{|c|}{ Abundance index (region) } & \multirow[b]{2}{*}{$6 a$} & \multirow[b]{2}{*}{$6 \mathrm{~b}$} & \multirow[b]{2}{*}{$7 a$} & \multirow[b]{2}{*}{$7 \mathrm{~b}$} & \multirow[b]{2}{*}{8} & \multirow[b]{2}{*}{ Tota } \\
\hline & $1 \mathrm{a}$ & $1 \mathrm{~b}$ & $2 a$ & $2 \mathrm{~b}$ & $3 a$ & $3 \mathrm{~b}$ & $4 \mathrm{a}$ & $4 \mathrm{~b}$ & $5 \mathrm{a}$ & $5 b$ & & & & & & \\
\hline 1970 & 0.08 & 0.09 & 0.09 & 0.34 & 0.06 & 0.06 & 0.07 & 0.16 & 0.04 & 0.06 & 0.03 & 0.05 & 0.02 & 0.09 & 0.17 & 1.41 \\
\hline 1971 & 0.10 & 0.16 & 0.13 & 0.12 & 0.06 & 0.08 & 0.06 & 0.12 & 0.03 & 0.10 & 0.03 & 0.05 & 0.01 & 0.09 & 0.29 & 1.41 \\
\hline 1972 & 0.11 & 0.28 & 0.04 & 0.10 & 0.03 & 0.07 & 0.04 & 0.21 & 0.03 & 0.39 & 0.03 & 0.05 & 0.02 & 0.09 & 0.17 & 1.66 \\
\hline 1973 & 0.03 & 0.16 & 0.07 & 0.11 & 0.04 & 0.07 & 0.04 & 0.09 & 0.04 & 0.12 & 0.03 & 0.16 & 0.04 & 0.21 & 0.43 & 1.64 \\
\hline 1974 & 0.02 & 0.09 & 0.05 & 0.06 & 0.02 & 0.07 & 0.04 & 0.11 & 0.02 & 0.04 & 0.03 & 0.01 & 0.02 & 0.09 & 0.11 & 0.77 \\
\hline 1975 & 0.04 & 0.09 & 0.05 & 0.24 & 0.04 & 0.08 & 0.05 & 0.10 & 0.03 & 0.20 & 0.02 & 0.10 & 0.02 & 0.09 & 0.12 & 1.26 \\
\hline 1976 & 0.08 & 0.23 & 0.10 & 0.14 & 0.08 & 0.16 & 0.08 & 0.24 & 0.06 & 0.29 & 0.04 & 0.15 & 0.03 & 0.18 & 0.24 & 2.10 \\
\hline 1977 & 0.00 & 0.09 & 0.04 & 0.13 & 0.06 & 0.08 & 0.07 & 0.17 & 0.05 & 0.16 & 0.02 & 0.12 & 0.01 & 0.09 & 0.04 & 1.13 \\
\hline 1978 & 0.01 & 0.02 & 0.12 & 0.13 & 0.06 & 0.06 & 0.06 & 0.15 & 0.05 & 0.13 & 0.04 & 0.07 & 0.02 & 0.09 & 0.12 & 1.12 \\
\hline 1979 & 0.03 & 0.03 & 0.04 & 0.10 & 0.06 & 0.11 & 0.05 & 0.17 & 0.01 & 0.06 & 0.03 & 0.01 & 0.00 & 0.09 & 0.15 & 0.93 \\
\hline 1980 & 0.03 & 0.08 & 0.14 & 0.08 & 0.05 & 0.07 & 0.06 & 0.17 & 0.04 & 0.12 & 0.03 & 0.03 & 0.02 & 0.07 & 0.06 & 1.03 \\
\hline 1981 & 0.09 & 0.05 & 0.05 & 0.03 & 0.02 & 0.02 & 0.03 & 0.03 & 0.02 & 0.10 & 0.03 & 0.05 & 0.02 & 0.09 & 0.27 & 0.90 \\
\hline 1982 & 0.01 & 0.01 & 0.03 & 0.09 & 0.01 & 0.00 & 0.02 & 0.02 & 0.01 & 0.00 & 0.03 & 0.05 & 0.02 & 0.09 & 0.00 & 0.40 \\
\hline 1983 & 0.04 & 0.03 & 0.04 & 0.01 & 0.04 & 0.01 & 0.04 & 0.06 & 0.02 & 0.11 & 0.03 & 0.03 & 0.02 & 0.09 & 0.03 & 0.59 \\
\hline 1984 & 0.08 & 0.08 & 0.01 & 0.17 & 0.07 & 0.04 & 0.08 & 0.12 & 0.05 & 0.18 & 0.05 & 0.11 & 0.02 & 0.12 & 0.75 & 1.94 \\
\hline 1985 & 0.07 & 0.10 & 0.08 & 0.23 & 0.04 & 0.06 & 0.04 & 0.17 & 0.03 & 0.14 & 0.03 & 0.05 & 0.02 & 0.02 & 0.49 & 1.56 \\
\hline 1986 & 0.05 & 0.14 & 0.04 & 0.05 & 0.04 & 0.02 & 0.03 & 0.06 & 0.01 & 0.03 & 0.03 & 0.03 & 0.01 & 0.03 & 0.10 & 0.68 \\
\hline 1987 & 0.05 & 0.09 & 0.01 & 0.05 & 0.04 & 0.05 & 0.05 & 0.12 & 0.02 & 0.07 & 0.02 & 0.01 & 0.02 & 0.09 & 0.22 & 0.90 \\
\hline 1988 & 0.07 & 0.17 & 0.03 & 0.01 & 0.02 & 0.01 & 0.04 & 0.02 & 0.01 & 0.04 & 0.03 & 0.05 & 0.02 & 0.09 & 0.01 & 0.62 \\
\hline 1989 & 0.10 & 0.18 & 0.06 & 0.05 & 0.04 & 0.02 & 0.03 & 0.05 & 0.02 & 0.04 & 0.02 & 0.05 & 0.02 & 0.09 & 0.09 & 0.84 \\
\hline 1990 & 0.04 & 0.08 & 0.04 & 0.04 & 0.03 & 0.02 & 0.04 & 0.05 & 0.02 & 0.06 & 0.03 & 0.01 & 0.02 & 0.09 & 0.12 & 0.67 \\
\hline 1991 & 0.01 & 0.09 & 0.01 & 0.01 & 0.02 & 0.02 & 0.01 & 0.03 & 0.03 & 0.10 & 0.00 & 0.01 & 0.02 & 0.09 & 0.02 & 0.47 \\
\hline 1992 & 0.02 & 0.02 & 0.06 & 0.03 & 0.04 & 0.02 & 0.03 & 0.03 & 0.03 & 0.05 & 0.04 & 0.01 & 0.02 & 0.09 & 0.01 & 0.49 \\
\hline 1993 & 0.04 & 0.09 & 0.07 & 0.13 & 0.03 & 0.03 & 0.05 & 0.11 & 0.03 & 0.04 & 0.02 & 0.03 & 0.02 & 0.09 & 0.15 & 0.92 \\
\hline 1994 & 0.00 & 0.00 & 0.03 & 0.00 & 0.05 & 0.01 & 0.04 & 0.04 & 0.01 & 0.03 & 0.01 & 0.01 & 0.02 & 0.10 & 0.01 & 0.36 \\
\hline 1995 & 0.04 & 0.07 & 0.04 & 0.00 & 0.04 & 0.04 & 0.06 & 0.09 & 0.04 & 0.10 & 0.03 & 0.04 & 0.04 & 0.02 & 0.17 & 0.82 \\
\hline 1996 & 0.01 & 0.01 & 0.01 & 0.01 & 0.02 & 0.00 & 0.03 & 0.01 & 0.01 & 0.00 & 0.03 & 0.05 & 0.01 & 0.04 & 0.17 & 0.42 \\
\hline 1997 & 0.05 & 0.03 & 0.07 & 0.10 & 0.06 & 0.09 & 0.08 & 0.14 & 0.05 & 0.10 & 0.05 & 0.02 & 0.01 & 0.09 & 0.33 & 1.27 \\
\hline 1998 & 0.04 & 0.08 & 0.10 & 0.14 & 0.07 & 0.06 & 0.09 & 0.14 & 0.04 & 0.12 & 0.03 & 0.03 & 0.02 & 0.09 & 0.22 & 1.27 \\
\hline Mean & 0.05 & 0.09 & 0.06 & 0.09 & 0.04 & 0.05 & 0.05 & 0.10 & 0.03 & 0.10 & 0.03 & 0.05 & 0.02 & 0.09 & 0.17 & 1.02 \\
\hline SD & 0.03 & 0.07 & 0.04 & 0.08 & 0.02 & 0.04 & 0.02 & 0.06 & 0.01 & 0.08 & 0.01 & 0.04 & 0.01 & 0.04 & 0.16 & 0.47 \\
\hline
\end{tabular}
in bold-face are means (all years) of the respective regions, as no data were available for those particular years and regions 
water (i.e. Atlantic inflow) measured along the transect at all stations and depths $(0,10,20,30,50,75,100 \mathrm{~m})$, $S_{x d}=$ observed salinity at stations from the surface to $100 \mathrm{~m}$, or the bottom when $d<100 \mathrm{~m}$; and $Z=$ observation depths $(\mathrm{m})$. The sum of the freshwater thickness calculated for Stns 2 and 3 were used as the coastal current index because these provided the longest available time series (Ólafsson 1985). In addition to these environmental effects, SSB data (in thousands of tons), derived from the most recent virtual population analysis (VPA) for the Icelandic cod stock (Anonymous 2000), were examined to provide an indication of the effect of spawning stock size on the origins of pelagic juvenile cod and subsequent recruitment at Age $3 \mathrm{yr}$.

Environmental and stock effects were examined in relation to the response variables of total relative abundance, mean total length, and the proportion of pelagic juvenile cod off the north coast that were estimated to originate from the main spawning component off the southwest coast. Initially, bivariate regressions of the response variables versus each of the environmental and stock predictor covariates were performed using locally weighted (LOESS) scatterplot smoothing to determine any underlying relationships (Cleveland et al. 1992). Linear LOESS regressions were used for each pair of variables, with a neighbourhood size of 0.75 of the total number of observations. The neighbourhood size or span of the LOESS smoother determines the fraction of the data used in smoothing at each point (Cleveland et al. 1992).

Generalized linear models (GLMs) were used to examine the multiplicative effect of the environmental and stock predictor covariates on each of the response variables (McCullagh \& Nelder 1989). An identity link function and Gaussian error distribution were used for the abundance and length data, and a logit link function and binomial error distribution for the proportion data. All the covariates were included in an initial model for each response variable. Backward stepwise variable selection and model fit were used to determine a set of significant covariates for the final GLMs based on analysis of deviance, approximate F-tests, and residual deviance plots. An additional measure of model fit was based on a pseudo-coefficient of determination $\left(\mathrm{R}^{2}\right)$, which was the fraction of the total 'variation' accounted for by the model:

$$
\mathrm{R}^{2}=1-\left(\frac{\text { residual deviance }}{\text { null deviance }}\right)
$$

where deviance was analagous to the residual sumsof-squares (Swartzman et al. 1992). Generalized additive models (GAMs) were then fitted to the final set of covariates for each response variable using cubic B-spline smoothers with 4 df (Hastie \& Tibshirani 1990). The effect of each covariate included in the re- spective GAMs were conditional on the other covariates in the models, and were demonstrated by their fitted contribution to each response variable plotted against the value of the covariate. Permutation tests and bootstrap resampling (500 samples) were used to derive the significance levels and confidence intervals for each of the covariates in the GAMs (for further details see Swartzman et al. 1992). Approximate F-tests based on changes in deviance were used to test whether the GAMs modelled the data significantly better than the GLMs (Hastie 1992).

Recruitment of 3 yr old cod was then examined in relation to the environmental and stock effects as well as the 0-group variables of total relative abundance, mean total length, and the proportion of pelagic juvenile cod estimated to originate from the main spawning component. Similar analyses were performed to those used for the 0-group variables. However, a log-link function to stabilize the variance of the residuals and Gaussian error distribution were used for the recruitment data. Modified Ricker (1954) stock-recruitment relationships were examined in relation to the significant predictor covariates to provide an understanding of environmental and stock effects on variable recruitment levels in the Icelandic cod stock. All statistical analyses were performed using the Version 5.1 S-PLUS software (MathSoft 1998).

\section{RESULTS}

\section{Spatial distribution, abundance, total length, and spawning origins of pelagic juvenile cod}

In August and September each year, most pelagic juvenile cod were generally found on the main nursery grounds off the north coast of Iceland (Regions 2 to 6 , mean proportion of total abundance index [ $\pm \mathrm{SD}$ ] all years combined $=59 \pm 11 \%$ ) (Fig. 3). In some years, large concentrations of pelagic juvenile cod were also found near Greenland (Region 8, $15 \pm 11 \%$ ), where they had presumably drifted with the northern and then western branch of the Irminger Current that deviates off the northwest coast (Figs. $2 \& 3$ ). Although, in any given year, most pelagic juvenile cod were found offshore (Regions $1 \mathrm{~b}$ to $7 \mathrm{~b}$ and $8,72 \pm 7 \%$ ), large numbers were also found in inshore waters (Regions $1 \mathrm{a}$ to $7 \mathrm{a}, 28 \pm 7 \%$ ) (Fig. 3)

Pelagic juvenile cod tended to be significantly larger in waters off the south coast of Iceland (Regions 1 and 7 , mean $[ \pm \mathrm{SD}]$ all years combined $=58 \pm 10 \mathrm{~mm}$ ) than those off the north coast (Regions 2 to $6,46 \pm 5 \mathrm{~mm}$ ), with little difference in mean total lengths between cod found in offshore $(48 \pm 5 \mathrm{~mm})$ and inshore (46 \pm $6 \mathrm{~mm}$ ) waters (Fig. 4). Similar spatial patterns were 
found in the age of pelagic juvenile cod (Marteinsdottir et al. 2000a). In addition, cod tended to hatch and spawn progressively later in a clockwise gradient from the west to the east coasts, providing support for differential spawning origins (Begg \& Marteinsdottir 2000, Marteinsdottir et al. 2000a). Consequently, the proportion of pelagic juvenile cod found on the main nursery grounds off the north coast (Regions 2 to 6 ) that were estimated to originate from the main spawning component off the southwest coast (Region 1) varied significantly between years (Fig. 5), possibly due to the strength and timing of the coastal current in concert with environmental and stock effects. Moreover, those cod that were estimated to originate from a later spawning than that of the main spawning component, most probably originated from other regional spawning components located around the country. Likewise, differential spawning in the south, besides that of the main spawning component off the southwest coast, was indicated in years when the spawning proportions in the south were $<1.0$ (Fig. 5).
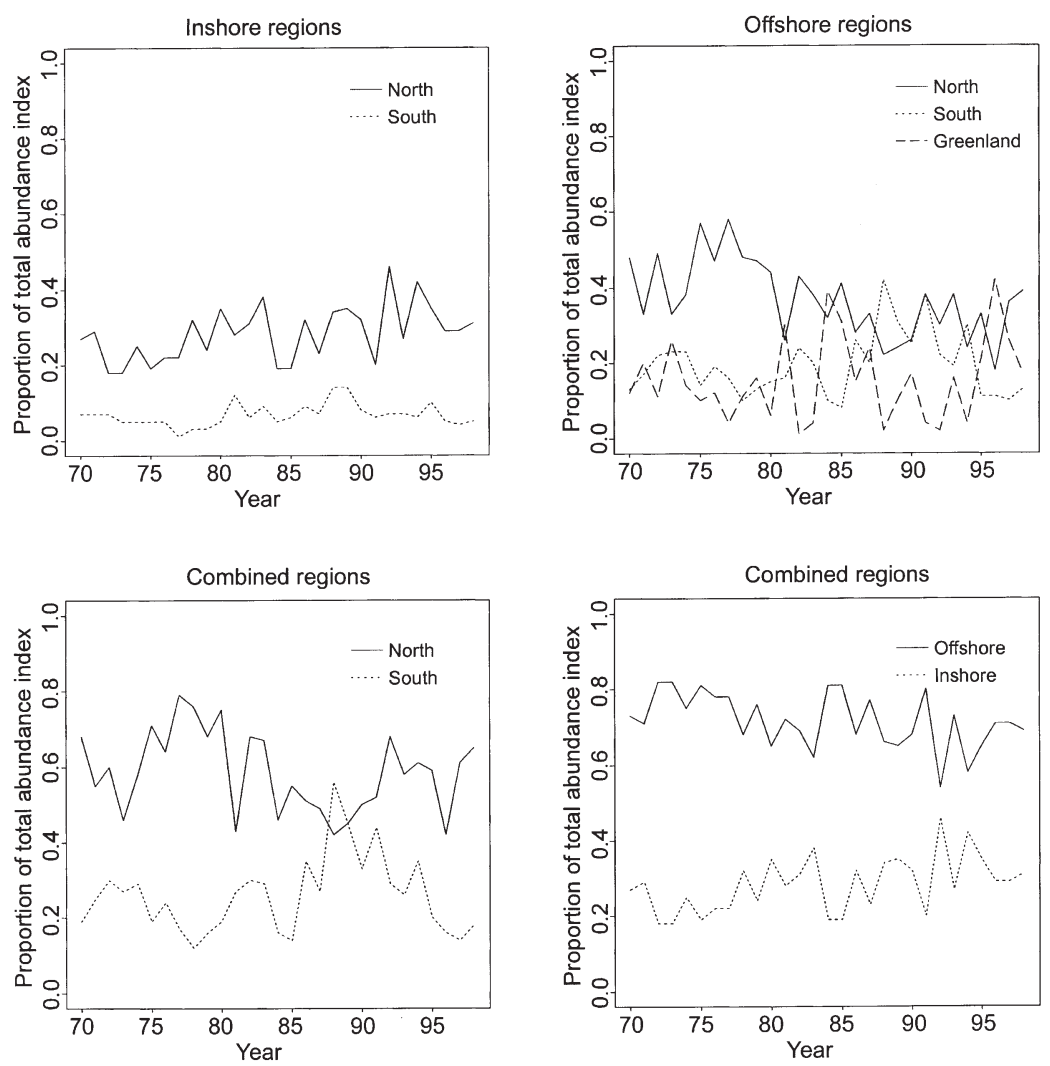

Fig. 3. Gadus morhua. Proportions of total relative abundance indices for pelagic juvenile cod off the north (Regions 2 to 6) and south (Regions 1 and 7) coasts of Iceland and Greenland (Region 8), and in inshore (Regions 1a to 7a) and offshore (Regions $1 \mathrm{~b}$ to $7 \mathrm{~b}$ and 8 ) waters, 1970 to 1998

\section{Environmental and stock effects on abundance, total length, and spawning origins of pelagic juvenile cod}

Exploratory data analysis suggested that the total relative abundance of pelagic juvenile cod was positively related to ambient temperature, strength of the coastal current, zooplankton biomass, and size of the spawning stock (Fig. 6). These trends were largely supported by the initial GLM, which found that the coastal current index, zooplankton biomass, and SSB were significant covariates affecting the total relative abundance of pelagic juvenile cod (Table 2). Likewise, the stepwise variable selection process found that the final best fitting, most parsimonious GLM included the same 3 covariates (Table 2). Results of the GAM indicated that total abundance of pelagic juvenile cod increased with the coastal current index, and was greatest when zooplankton biomass and SSB were above $3.5 \mathrm{~g} \mathrm{dw} \mathrm{m}^{-2}$ and $475000 \mathrm{t}$, respectively (Fig. 7). However, there was no significant difference between the final GLM and GAM ( $p>0.6758$, Fig. 8). Selection of the final GLM was supported by the lack of structure in the deviance residuals relative to the predicted values (Fig. 8).
The mean total length of pelagic juvenile cod was positively related to ambient temperature, and strength of the coastal current (Fig. 6). The initial GLM found that the coastal current index significantly affected the mean total length of pelagic juvenile cod, while temperature was marginally non-significant (Table 2). However, the stepwise variable selection process included both the coastal current index and temperature as significant covariates in the final GLM (Table 2). Model selection was also supported by the apparent lack of structure in the deviance residuals relative to the predicted values (Fig. 8). The GAM indicated that the mean total length of pelagic juvenile cod was greatest when the coastal current index was between 0.6 and $1.3 \mathrm{~m}$ and the temperature was above $6.5^{\circ} \mathrm{C}$ (Fig. 7). There was no significant difference between the final GLM and GAM ( $p>0.1867$; Fig. 8).

The proportion of pelagic juvenile cod found on the main nursery grounds off the north coast (Regions 2 to 6) that were estimated to originate from the main spawning component off the southwest coast (Region 1) was positively related only to strength of the coastal current (Fig. 6). Similarly, both the initial and 

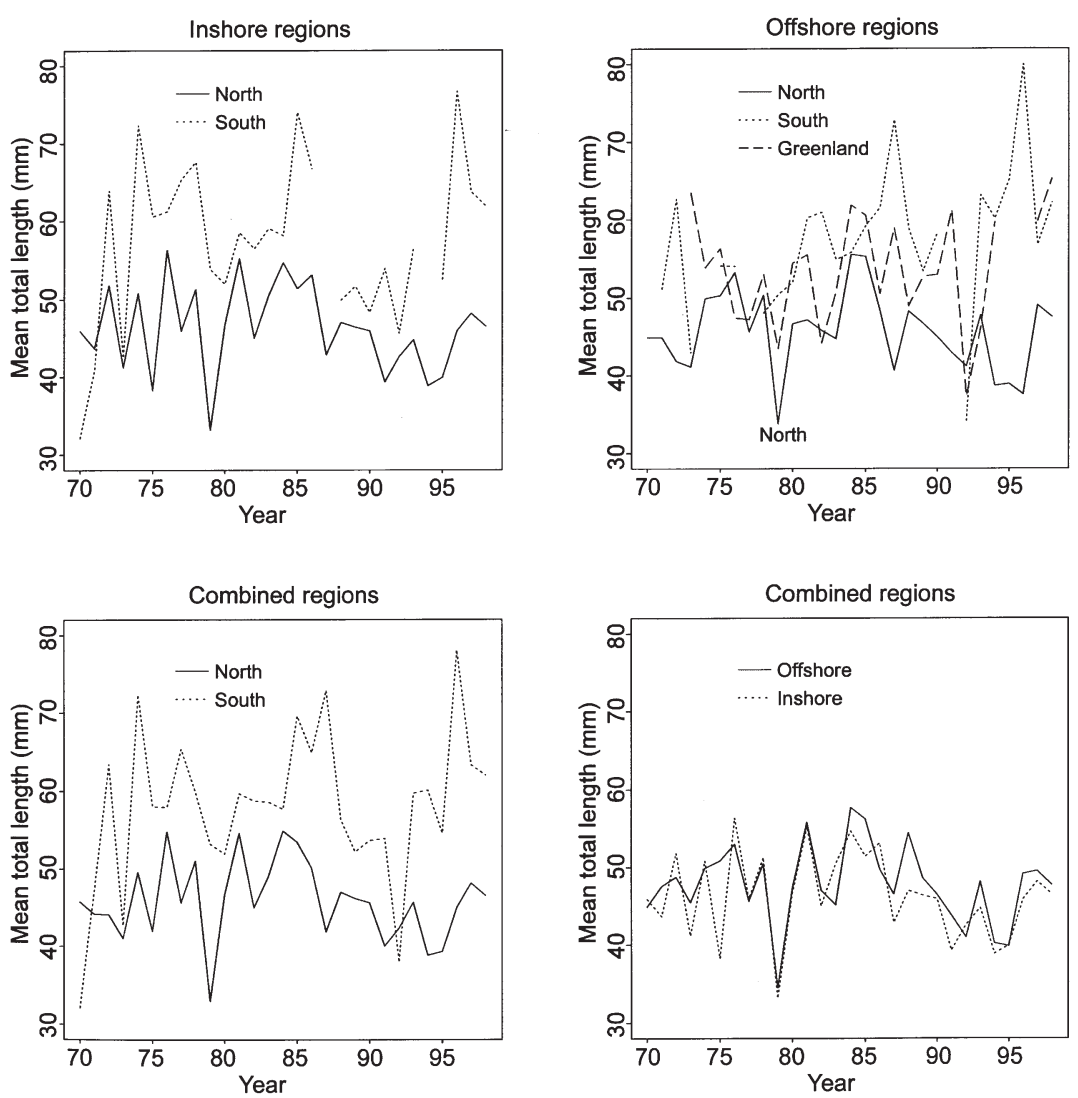

Fig. 4. Gadus morhua. Mean adjusted (20 August) total lengths (mm) of pelagic juvenile cod off the north and south coasts of Iceland and Greenland, and from inshore and offshore waters, 1970 to 1998. Regions as in Fig. 3 legend final stepwise GLM indicated that only the coastal current index was a significant covariate affecting the proportion of pelagic juvenile cod originating from the main spawning component (Table 2). The coastal current index was also a significant covariate in the GAM (Table 2), whereby the greatest proportion of pelagic juvenile cod in the north that originated from the main spawning component in the southwest tended to occur when the coastal current index was around $1.0 \mathrm{~m}$ (Fig. 7). The GAM was significantly different from the final GLM ( $\mathrm{p}<0.0246)$, and provided a better fit to the data (Table 2, Fig. 8). Selection of the final GAM was additionally supported by the apparent lack of structure in the deviance residuals relative to the predicted values (Fig. 8).

\section{Implications of spawning origins and environmental and stock effects on recruitment}

Recruitment of 3 yr old cod was positively related to strength of the coastal current, zooplankton biomass, and

Table 2. Gadus morhua. Significance (p) of the environmental and stock-predictor covariates of temperature (Tem), salinity (Sal), coastal current index (Cur), zooplankton biomass (Zoo), and spawning stock biomass (SSB) on the response variables of total relative abundance, mean total length, proportion of pelagic juvenile cod estimated to originate from the main spawning component off the southwest coast, and $\log _{\mathrm{e}}$-transformed recruitment of $3 \mathrm{yr}$ old cod for each initial and final stepwise $\left({ }^{*}\right)$ generalized linear model (GLM), and corresponding generalized additive model (GAM). Significance (p) of the covariates in the GAMs was derived from permutation tests; number of permutations used in each test was 500. Also shown are the null and residual model deviance, degrees of freedom (df) for each deviance term, and the pseudo-coefficient of determination $\left(R^{2}\right)$ for each model

\begin{tabular}{|c|c|c|c|c|c|c|c|c|c|c|}
\hline \multirow{2}{*}{$\begin{array}{l}\text { Response variable, } \\
\text { Model }\end{array}$} & \multirow[b]{2}{*}{ Tem } & \multicolumn{4}{|c|}{ p-values of predictor covariates } & \multirow{2}{*}{$\begin{array}{l}\text { Null } \\
\text { dev. }\end{array}$} & \multirow[t]{2}{*}{ df } & \multirow{2}{*}{$\begin{array}{l}\text { Res } \\
\text { dev. }\end{array}$} & \multirow[t]{2}{*}{ df } & \multirow[t]{2}{*}{$\mathrm{R}^{2}$} \\
\hline & & Sal & Cur & Zoo & SSB & & & & & \\
\hline \multicolumn{11}{|l|}{ Abundance } \\
\hline GLM & 0.1659 & 0.4913 & 0.0290 & 0.0089 & 0.0104 & 6.00 & 27 & 2.87 & 22 & 0.52 \\
\hline GLM $^{*}$ & - & - & 0.0364 & 0.0188 & 0.0130 & 6.00 & 27 & 3.39 & 24 & 0.44 \\
\hline GAM & - & - & 0.3580 & 0.2600 & 0.1080 & 6.00 & 27 & 2.36 & 15.0 & 0.61 \\
\hline \multicolumn{11}{|l|}{ Mean length } \\
\hline GLM & 0.0611 & 0.7368 & 0.0370 & 0.7154 & 0.1576 & 751.31 & 27 & 497.59 & 22 & 0.34 \\
\hline GLM $^{*}$ & 0.0393 & - & 0.0448 & - & - & 751.31 & 27 & 549.33 & 25 & 0.27 \\
\hline GAM & 0.6800 & - & 0.0220 & - & - & 751.31 & 27 & 360.76 & 19.0 & 0.52 \\
\hline \multicolumn{11}{|l|}{ Proportion } \\
\hline GLM & 0.0878 & 0.4256 & 0.0213 & 0.3184 & 0.3571 & 4.09 & 27 & 2.70 & 22 & 0.34 \\
\hline GLM $^{*}$ & - & - & 0.0572 & - & - & 4.09 & 27 & 3.47 & 26 & 0.15 \\
\hline GAM & - & - & 0.0240 & - & - & 4.09 & 27 & 2.38 & 23.0 & 0.42 \\
\hline \multicolumn{11}{|l|}{$\operatorname{Loq}_{\mathrm{e}}$ (recruitment) } \\
\hline GLM & 0.9694 & 0.5410 & 0.0653 & 0.1647 & 0.1222 & 5.29 & 27 & 3.78 & 22 & 0.29 \\
\hline GLM $^{*}$ & - & - & 0.0823 & - & 0.0597 & 5.29 & 27 & 4.11 & 25 & 0.22 \\
\hline GAM & - & - & 0.2760 & - & 0.0840 & 5.29 & 27 & 2.80 & 19.0 & 0.47 \\
\hline
\end{tabular}



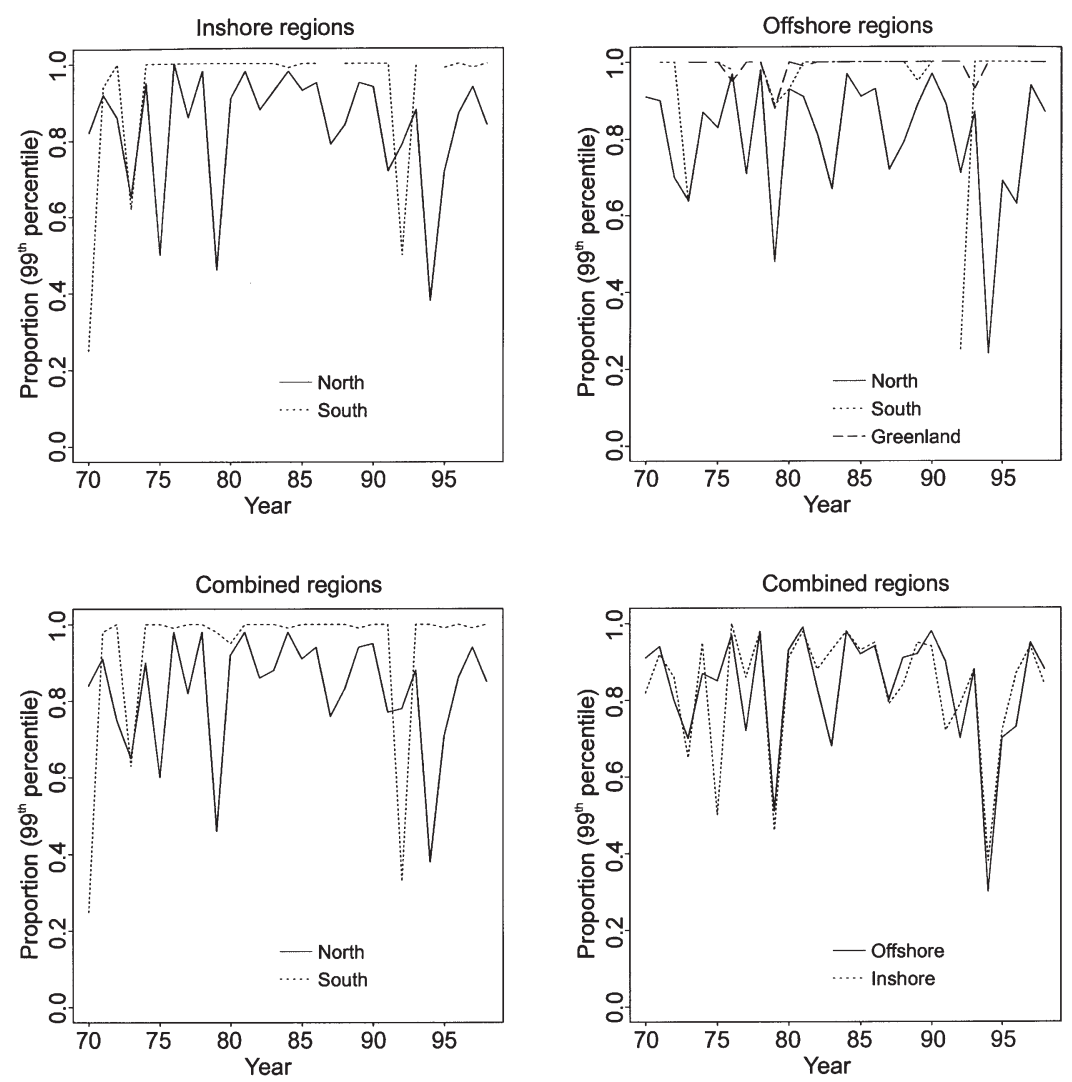

Fig. 5. Gadus morhua. Proportions of pelagic juvenile cod which were estimated to originate from the main spawning component off the southwest coast (Region 1) for cod from the north and south coasts of Iceland and Greenland, and from inshore and offshore waters, 1970 to 1998. Proportions are based on the number of cod spawned before the 99th spawning distribution percentile (Julian Day 159) (see Begg \& Marteinsdottir 2000 for details). Regions as in Fig. 3 legend mean total length, and proportion of pelagic juvenile cod originating from the main spawning component) (Fig. 6). However, only total relative abundance of pelagic juvenile cod significantly contributed to the final GLM which included the coastal current index and SSB ( $p<0.0025)$.

A modified Ricker (1954) stockrecruitment relationship incorporating the effect of the coastal current index significantly improved the amount of variation in recruitment explained by the model compared to the standard stock-recruitment relationship ( $p<0.0339$, Fig. 9). Greater recruitment of Age 3 cod was predicted with increasing strength of the coastal current (Fig. 9).

\section{DISCUSSION}

Recruitment success derived from individual spawning components is most probably dependent upon favourable environmental and stock effects that influence the dispersal and survival of early life-history stages. Differentiation of the effects of these variables on pelagic juveniles and earlier life-history stages, therefore, is necessary for resolving recruitment variability in marine fish stocks, particularly as year-class strength is considered to be governed by growth and mortality of these initial stages (Cushing 1973, Campana et al. 1989, Mertz \& Myers 1994). In this study, we found that spawning origins and demographic characteristics of pelagic juvenile cod in Icelandic waters were significantly related to physical transport mechanisms, ambient environmental conditions, food availability, and size of the spawning stock. Moreover, these relationships were also evident at the age of recruitment, indicating the persistence of these effects throughout the life history and the significance of early life-history stages on the recruitment dynamics of Icelandic cod.

Pelagic juvenile cod are distributed all around Iceland following peak spawning of adult cod between late March and early May (Astthorsson et al. 1994, Begg \& Marteinsdottir 2000). Back-calculated birthdate distributions suggest that the majority of pelagic juveniles originate from the main spawning component off the southwest coast, and are mostly found in August and September on the main nursery grounds the 0 -group variables (i.e. total relative abundance, 


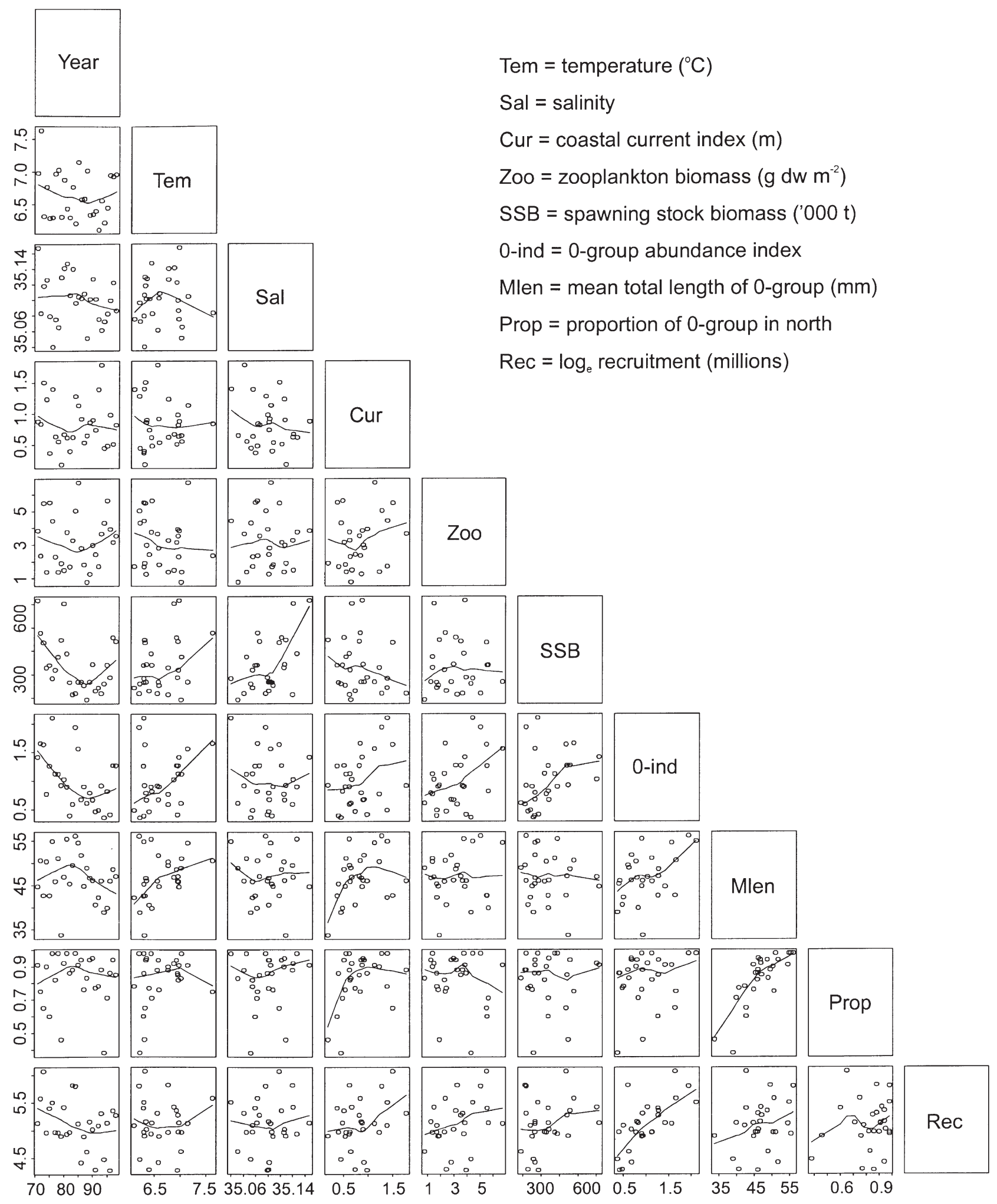

Fig. 6. Gadus morhua. Bivariate regressions of the total relative abundance index (0-ind), mean total length (Mlen), proportion of pelagic juvenile cod in the north estimated to originate from the main spawning component off the southwest coast (Prop), and $\log _{\mathrm{e}}$-transformed recruitment at Age $3 \mathrm{yr}(\mathrm{Rec})$, and the environmental and stock predictor covariates of temperature (Tem), salinity (Sal), coastal current index (Cur), zooplankton biomass (Zoo), and spawning stock biomass (SSB in thousands of tons), 1970 to 1998 . Lines represent the best fitting linear LOESS regressions 

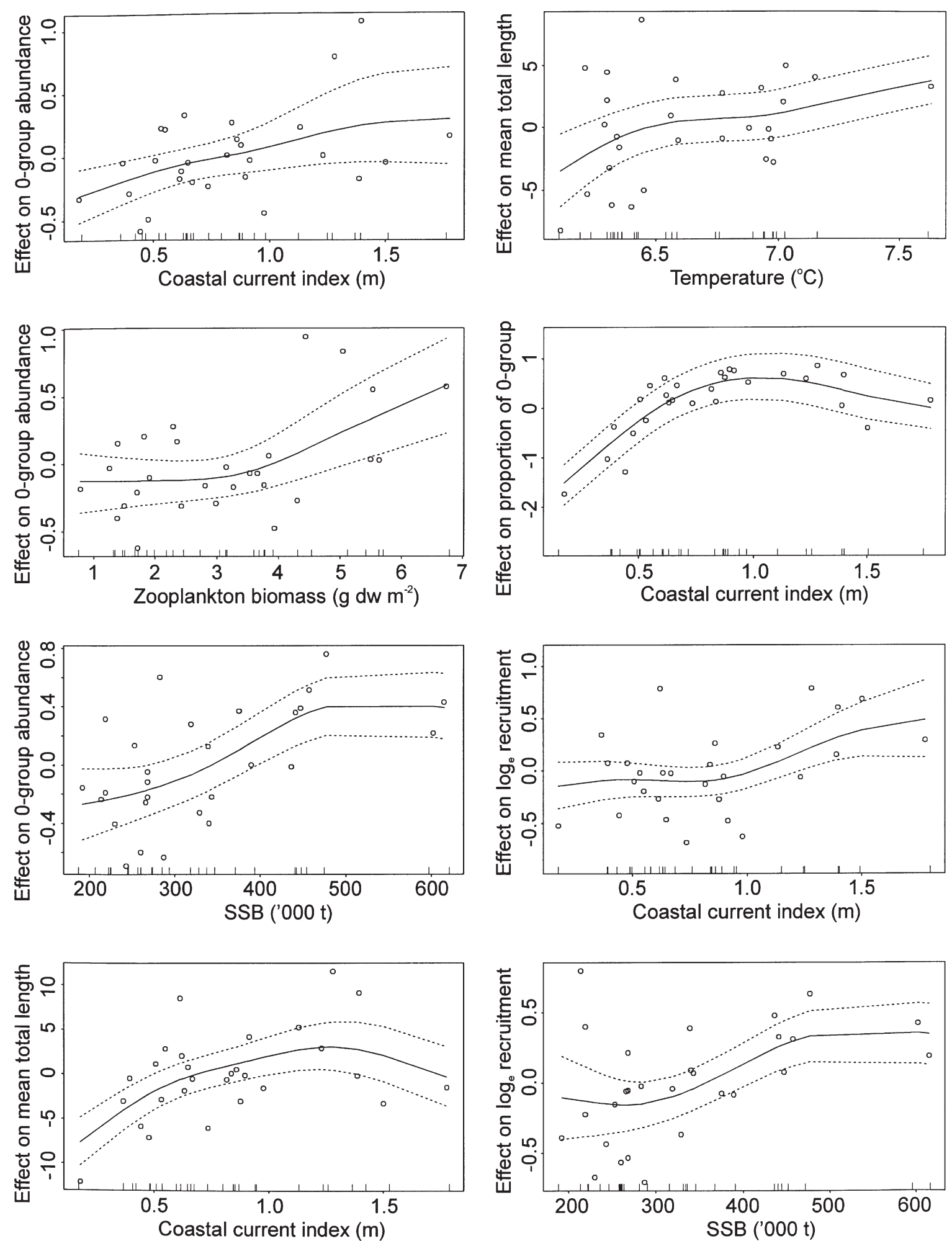

Fig. 7. Gadus morhua. GAM smooths of the conditional effects of the significant covariates (coastal current index, zooplankton biomass, SSB [thousands of tons] and temperature) on the total relative abundance index, mean total length (mm), proportion of pelagic juvenile cod ( 0 -group) in the north estimated to originate from the main spawning component off the southwest coast, and $\log _{\mathrm{e}}$-transformed recruitment at Age $3 \mathrm{yr}$ (millions). The $y$-axis is scaled to zero and reflects the relative importance of the covariate; rugplot on the $x$-axis represents the number of observations; dashed lines are $95 \%$ confidence intervals on the smooths generated from bootstrap resampling $(500 \times)$ of the original data 

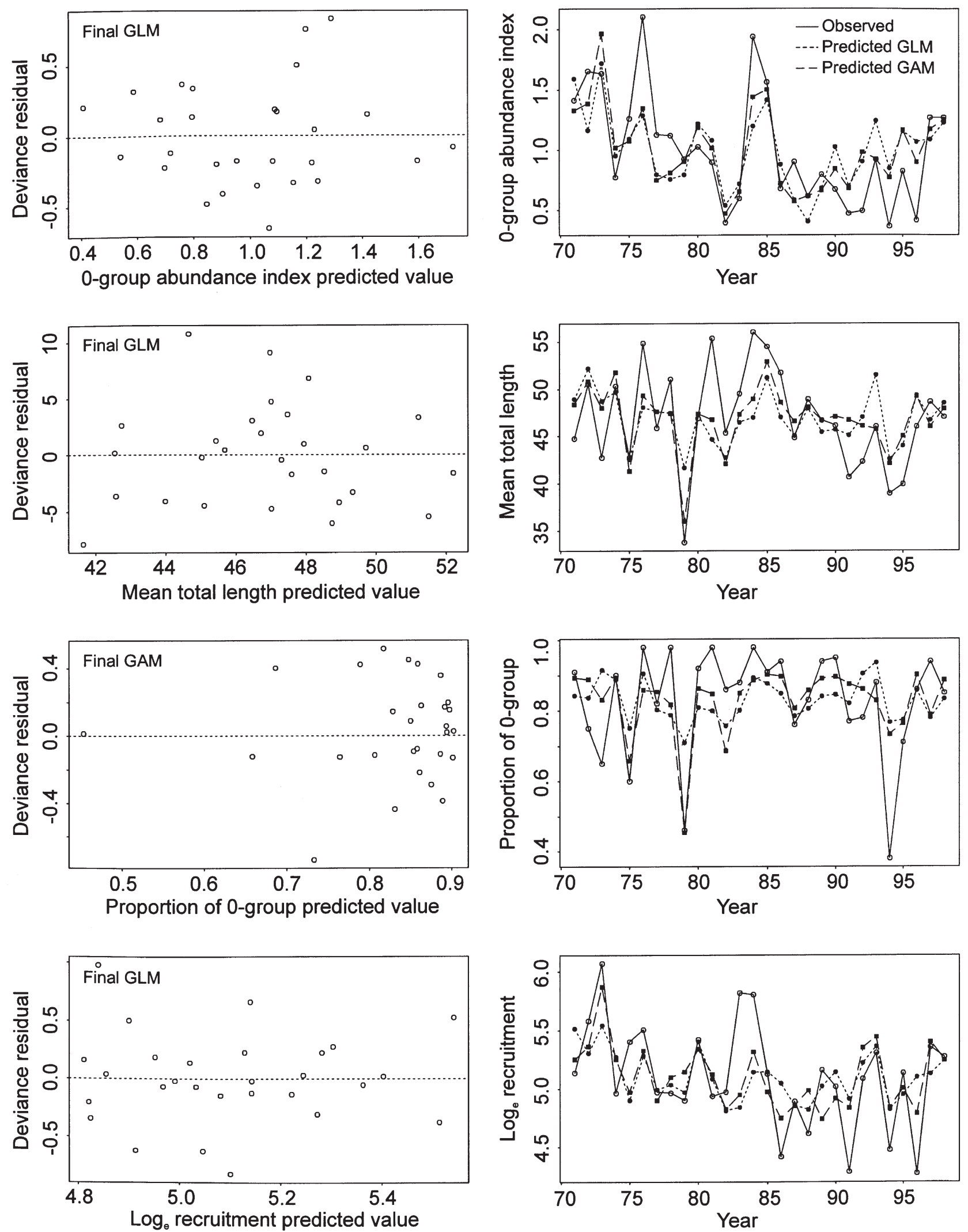

Fig. 8. Gadus morhua. Deviance residual plots of final model fits, and annual predicted versus observed values for final GLMs and GAMs, 1971 to 1998 

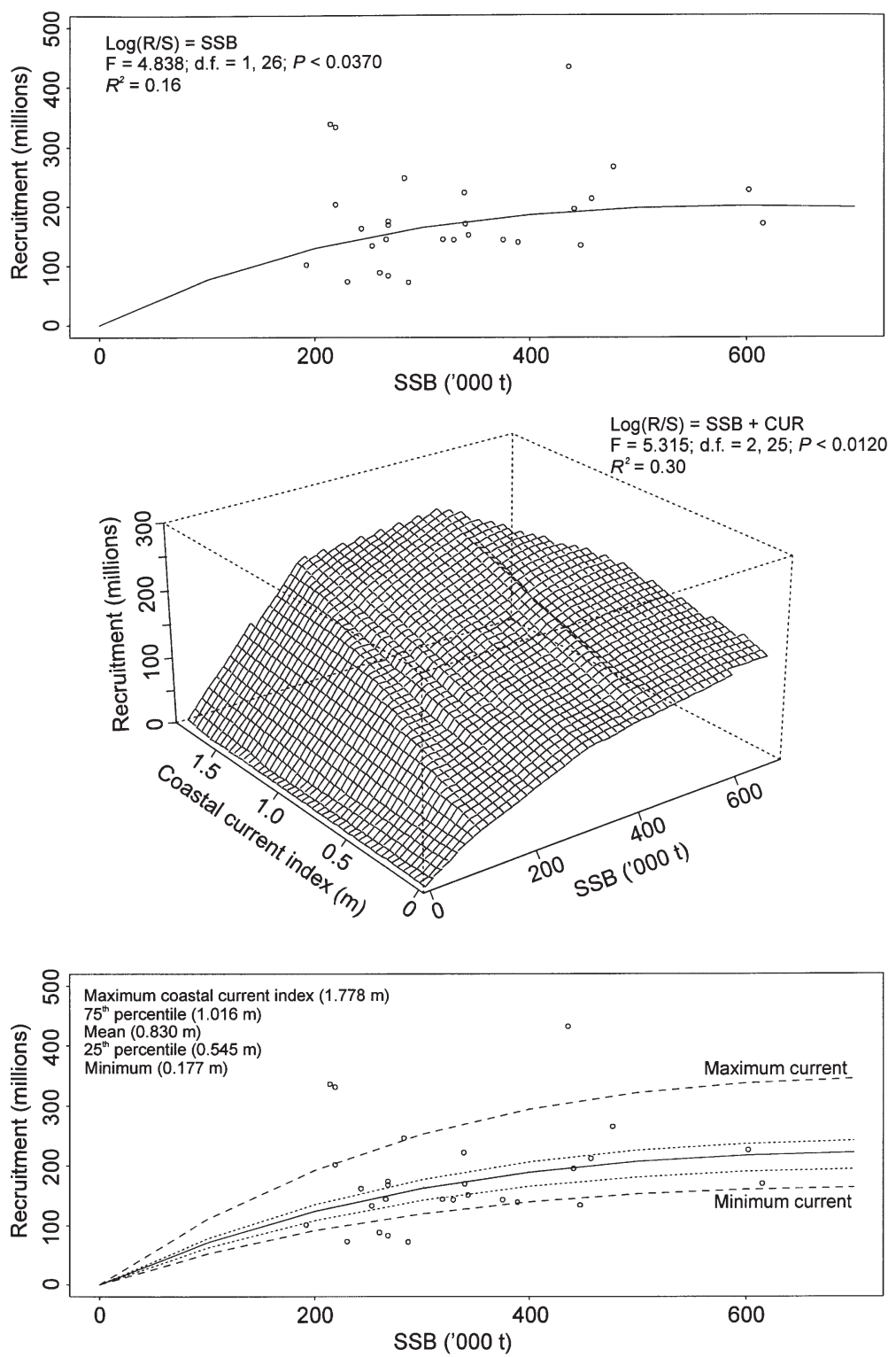

Fig. 9. Gadus morhua. Modified Ricker (1954) stock-recruitment relationships incorporating the effects of SSB (thousands of tons) and the coastal current index

off the north coast (Begg \& Marteinsdottir 2000, Marteinsdottir et al. 2000a, and present Figs. 3 \& 5). However, in any given year, significant quantities of pelagic juvenile cod may also originate from smaller, regional spawning components located all around Iceland, dependent on localized environmental and stock effects (Fig. 5), thereby supplementing the recruits derived from the main spawning component (Begg \& Marteinsdottir 2000). Localized spawning in waters off the west, north and east coasts has also been inferred from groundfish and ichthyoplankton research surveys, and commercial catch data (Jónsson 1982, Mar- teinsdottir et al. 2000a, Begg \& Marteinsdottir 2001, in this issue). However, localized spawning in regions outside the main spawning grounds have traditionally been viewed to be limited, and even non-existent, in some years (Sæmundsson 1924, Jónsson 1982), despite early observations of persistent inshore spawning off the north and east coasts (Fridriksson 1933). These traditional views were largely based on anecdotal evidence and data collected from offshore sampling of the main spawning grounds with limited spatial coverage elsewhere, particularly within the fjords and inshore waters (i.e. Jónsson 1982). Significant inshore spawning has been observed in cod stocks throughout the north Atlantic (Hurley \& Campana 1989, Hutchings et al. 1993, Anderson et al. 1995), and also in the Icelandic cod stock (Jónsson 1982, Marteinsdottir et al. 2000b). Future studies need to investigate the extent of regional spawning in waters around Iceland, particularly within the fjords and inshore waters, that may be contributing significantly more to the overall productivity of the stock than has been traditionally accepted (Begg \& Marteinsdottir 2000, Marteinsdottir et al. 2000a). Identifying the individual components that comprise a spawning stock is an essential first step in understanding the recruitment dynamics of marine fish stocks.

Differentiating environmental and stock effects on early life-history stages is also an important step to understanding the factors that govern recruitment dynamics. Environmental effects have long been recognized as important mechanisms in population regulation (Cushing 1982), but are rarely considered in routine stock assessments (Myers 1998), partly because of the difficulties in distinguishing the effects of the environment from that of the fishery (Mountain \& Murawski 1992). Furthermore, the mechanisms controlling recruitment are most probably mediated via complex physical and biological interactions, and these are rarely known for most fish stocks (DeYoung \& Rose 1993, Daan 1994). However, uncoupling the effects of these interactions on the population dynamics of early life-history stages is fundamental to comprehending recruitment variability. We found that the coastal current index, ambient temperature, zooplankton biomass, and SSB were all significant factors affecting the spawning origins and demographic characteristics of 
pelagic juvenile cod in Icelandic waters (Figs. 6 \& 8). Notably, some of these effects were carried through to the age of recruitment indicating the probable establishment of these relationships at an earlier life-history stage (Figs. 6, 8 \& 9).

The strength of the coastal current was the most dominant factor affecting the spatial distribution, abundance, size, and spawning origins of pelagic juvenile cod, as well as recruitment. Likewise, Johannessen \& Tveite (1989) found that recruitment variability in cod off the Norwegian Skagerrak coast was primarily due to the physical conditions experienced during early life-history stages. Ocean physics play an important role in the retention or dispersal of progeny to favourable nursery grounds and habitats (Sinclair 1988), directly influencing year-class strength and subsequent recruitment success (Anderson \& Dalley 1997). Distributions of a spawning component most probably represent adaptations to the physical dispersive properties of a geographic region that optimize progeny survival through their initial spatial and temporal placement (Sinclair 1988, Heath 1992). Accordingly, the west- and northward-flowing coastal current off Iceland, induced by freshwater runoff, results in an inshore clockwise flow around the country (Ólafsson 1985), providing a predictable transport mechanism for pelagic eggs and larvae derived from the main spawning component off the southwest coast to the main nursery grounds off the north coast (Marteinsdottir et al. 2000b). Typically, in years when the coastal current was strong, more abundant and larger pelagic juveniles derived from the main spawning component were found on the main nursery grounds. Moreover, these effects tended to cascade through to years of good recruitment (Ólafsson 1985, present Fig. 9).

Larger, older, and more fecund cod tend to spawn in inshore waters of the main spawning grounds, where the effect of the coastal current is more pronounced (Marteinsdottir et al. 2000b). Recent studies suggest that more viable progeny with greater survivorship traits are produced from these larger, older spawners than those from smaller, younger spawners (Kjesbu et al. 1996, Marteinsdottir \& Steinarsson 1998, Trippel 1998). Hence, spawning in inshore waters of the main spawning grounds may be a genetically predetermined or favourable behavioural trait of Icelandic cod that optimizes progeny survival by increasing the chance of more viable eggs and larvae being dispersed by the coastal current to the main nursery grounds in the north (Marteinsdottir et al. 2000b). Importantly, the spatial and temporal occurrence of this drift route coincides with peak abundance of zooplankton (Astthorsson et al. 1994), supporting the match/mismatch hypothesis of Cushing (1969). This occurrence was reflected in the positive effect of zooplankton biomass on the abundance of pelagic juvenile cod, whereby greater food availability appeared to have a beneficial affect on progeny survival (Astthorsson et al. 1994, and present Fig. 6). Likewise, warmer ambient temperatures experienced by first-feeding larvae along the main drift route appeared to have similar beneficial affects on progeny growth (Fig. 6).

The size of the spawning stock also had a significant positive effect on the abundance of pelagic juvenile cod and subsequent recruitment to the stock. Not unexpectedly, when SSB was large, recruitment also tended to be large (Fig. 9); supporting the extensive stock-recruitment analyses of Myers \& Barrowman (1996). However, as for many other fish stocks, this relationship for Icelandic cod was highly variable (Cushing 1973, Gulland 1983), casting doubt on its utility in recruitment prediction (Marshall et al. 1998). Recently, this has resulted in the search for more sensitive measures of stock status (Marshall et al. 1998) and the need to account for the effects of individual spawning components (Begg \& Marteinsdottir 2000) and the age and size diversity of spawning fish (Marteinsdottir \& Thorarinsson 1998). Notably, recruitment prediction was improved significantly with the addition of the coastal current index to the stock-recruitment relationship, emphasizing the need to account for environmental effects that influence the dispersal and survival of the important early life-history stages (Fig. 9). Moreover, the total relative abundance of pelagic juvenile cod was a better predictor in explaining recruitment variability $\left(\mathrm{R}^{2}=0.50\right)$ than SSB $\left(\mathrm{R}^{2}=0.20\right)$ (Fig. 6). In contrast, our estimated proportions of pelagic juvenile cod in the north which had originated from the main spawning component in the southwest was not as well correlated with recruitment $\left(\mathrm{R}^{2}=0.24\right)$ as that of the total abundance index (Fig. 6), demonstrating the importance of also incorporating the effects of all spawning components in recruitment prediction. Hence, future studies need to examine the composition of individual spawning components which comprise a fish stock relative to environmental and physical effects if we are to refine recruitment prediction. Studies such as the present study provide insight into potentially important mechanisms which influence stock and recruitment, and demonstrate the links between early life-history stages, primary production, and physical transport mechanisms.

The traditional view of the Icelandic cod stock is one of a single, homogeneous unit, in which year-class strength and recruitment are governed by the population dynamics of the main spawning component off the southwest coast (Sæmundsson 1924, Jónsson 1982). However, recent studies indicate greater spawning diversity within the Icelandic cod stock than has been traditionally viewed (Begg \& Marteinsdottir 2000, 
Jónsdottir et al. 1999, Marteinsdottir et al. 2000a). Consequently, these views need to be revised and, more importantly, incorporated into the assessment and management process. Failure to account for stock diversity can lead to erosion of spawning components, with unknown ecological consequences (Stephenson 1999). Furthermore, incorporating environmental and stock effects on the growth and survival of early lifehistory stages will facilitate our understanding of recruitment variability and lead to better estimates of the stock-recruitment relationship.

Acknowledgements. Our thanks to Sveinn Sveinbjornsson and Vilhelmina Jakobsson for access to the 0-group data; Jón Olafsson for discussions and use of the coastal current data; Astthor Gislason for the zooplankton data; Svend-Aage Malmberg, Hédinn Valdimarsson and John Mortensen for discussions on hydrographic conditions; Lorna Taylor for statistical advice; and Brian MacKenzie and 3 anonymous reviewers for their constructive comments. This study was part of the EU funded project, FAIR-PL98-4122, 'An operational model of the effects of stock structure and spatio-temporal factors on recruitment (STEREO)', and was supported by the Icelandic Research Council and the Ministry of Fisheries.

\section{LITERATURE CITED}

Anderson JT, Dalley EL (1997) Spawning and year-class strength of northern cod (Gadus morhua) as measured by pelagic juvenile cod surveys, 1991-1994. Can J Fish Aquat Sci 54(Suppl 1):158-167

Anderson JT, Dalley EL, Carscadden JE (1995) Abundance and distribution of pelagic 0-group cod (Gadus morhua) in Newfoundland waters: inshore versus offshore. Can J Fish Aquat Sci 52:115-125

Anonymous (1999) Environmental conditions in Icelandic waters 1997 and 1998. Hafrannsóknastofnun Fjölrit 73: $1-48$

Anonymous (2000) State of marine stocks in Icelandic waters 1999/2000. Hafrannsóknastofnun Fjölrit 75:1-176

Astthorsson OS, Gislason A, Gudmundsdottir A (1994) Distribution, abundance, and length of pelagic juvenile cod in Icelandic waters in relation to environmental conditions. ICES Mar Sci Symp 198:529-541

Begg GA, Marteinsdottir G (2000) Spawning origins of pelagic juvenile cod Gadus morhua inferred from spatially explicit age distributions: potential influences on yearclass strength and recruitment. Mar Ecol Prog Ser 202: 193-217

Begg GA, Marteinsdottir G (2002) Environmental and stock effects on spatial distribution and abundance of mature cod Gadus morhua. Mar Ecol Prog Ser 229:245-262

Beverton RJH, Holt SJ (1957) On the dynamics of exploited fish populations. Fish Investig Ser II Mar Fish GB Minist Agric Fish Food 19:1-533

Campana SE, Frank KT, Hurley PCF, Koeller PA, Page FH, Smith PC (1989) Survival and abundance of young Atlantic cod (Gadus morhua) and haddock (Melanogrammus aeglefinus) as indicators of year class strength. Can J Fish Aquat Sci 46(Suppl 1):171-182

Cleveland WS, Grosse E, Shyu WM (1992) Local regression models. In: Chambers JM, Hastie TJ (eds) Statistical models. Chapman and Hall, London, p 309-376

Cook RM, Sinclair A, Stefánsson G (1997) Potential collapse of North Sea cod stocks. Nature 385:521-522

Cushing DH (1969) The regularity of the spawning season of some fishes. J Cons Int Explor Mer 33:81-97

Cushing DH (1973) Dependence of recruitment on parent stock. J Fish Res Board Can 30:1965-1976

Cushing DH (1982) Climate and fisheries. Academic Press, London

Daan N (1994) Trends in North Atlantic cod stocks: a critical summary. ICES Mar Sci Symp 198:269-270

DeYoung B, Rose GA (1993) On recruitment and distribution of Atlantic cod (Gadus morhua) off Newfoundland. Can J Fish Aquat Sci 50:2729-2741

Fridriksson A (1933) Fiskirannsóknir. Ársrit Fiskif Ísl 1932(2): $1-77$ (in Icelandic)

Gulland JA (1983) Fish stock assessment: a manual of basic methods. Wiley, New York

Hastie TJ (1992) Generalized additive models. In: Chambers JM, Hastie TJ (eds) Statistical models. Chapman and Hall, London, p 249-307

Hastie TJ, Tibshirani RJ (1990) Generalized additive models. Chapman \& Hall, London

Heath MR (1992) Field investigations of the early life stages of marine fish. Adv Mar Biol 28:1-174

Hilborn R, Walters CJ (1992) Quantitative fisheries stock assessment: choice, dynamics, and uncertainty. Chapman \& Hall, New York

Hurley PCF, Campana SE (1989) The distribution and abundance of haddock (Melanogrammus aeglefinus) and Atlantic cod (Gadus morhua) eggs and larvae in the waters of southwestern Nova Scotia. Can J Fish Aquat Sci 46(Suppl. 1):103-112

Hutchings JA (1996) Spatial and temporal variation in the density of northern cod and a review of hypotheses for the stock's collapse. Can J Fish Aquat Sci 53:943-962

Hutchings JA, Myers RA, Lilly GR (1993) Geographic variation in the spawning of Atlantic cod, Gadus morhua, in the northwest Atlantic. Can J Fish Aquat Sci 50: $2457-2467$

Johannessen T, Tveite S (1989) Influence of various physical environmental factors on 0 -group cod recruitment by partial least-squares regression. Rapp PV Réun Cons Int Explor Mer 191:311-318

Jónsdottir ODB, Imsland AK, Danielsdottir AK, Thorsteinsson V, Nævdal G (1999) Genetic differentiation among Atlantic cod in south and south-east Icelandic waters: synaptophysin (Syp I) and haemoglobin $(\mathrm{Hbl})$ variation. J Fish Biol 54:1259-1274

Jónsson E (1982) A survey of spawning and reproduction of the Icelandic cod. Rit Fiskid 6:1-45

Kjesbu OS, Solemdal P, Bratland P, Fonn M (1996) Variation in annual egg production in individual captive Atlantic cod (Gadus morhua). Can J Fish Aquat Sci 53:610-620

Malmberg SA, Kristmannsson SS (1992) Hydrographic conditions in Icelandic waters, 1980-1989. ICES Mar Sci Symp 195:76-92

Marshall CT, Kjesbu OS, Yaragina NA, Solemdal P, Ulltang Ø (1998) Is spawner biomass a sensitive measure of the reproductive and recruitment potential of Northeast Arctic cod? Can J Fish Aquat Sci 55:1766-1783

Marteinsdottir G, Steinarsson A (1998) Maternal influence on the size and viability of Iceland cod Gadus morhua eggs and larvae. J Fish Biol 52:1241-1258

Marteinsdottir G, Thorarinsson K (1998) Improving the stockrecruitment relationship in Icelandic cod (Gadus morhua) 
by including age diversity of spawners. Can J Fish Aquat Sci 55:1372-1377

Marteinsdottir G, Gunnarsson B, Suthers IM (2000a) Spatial variation in hatch date distributions and origin of pelagic juvenile cod in Icelandic waters. ICES J Mar Sci 57: 1184-1197

Marteinsdottir G, Gudmundsdottir A, Porsteinsson V, Stefánsson G (2000b) Spatial variation in abundance, size composition and viable egg production of spawning cod (Gadus morhua L.) in Icelandic waters. ICES J Mar Sci $57: 824-830$

MathSoft (1998) S-PLUS 5 for unix guide to statistics. Data Analysis Products Division, MathSoft, Seattle, WA

McCullagh P, Nelder JA (1989) Generalized linear models, 2nd edn. Chapman \& Hall, London

Mertz G, Myers RA (1994) Match/mismatch predictions of spawning duration versus recruitment variability. Fish Oceanogr 3:236-245

Mountain DG, Murawski SA (1992) Variation in the distribution of fish stocks on the northeast continental shelf in relation to their environment, 1980-1989. ICES Mar Sci Symp 195:424-432

Myers RA (1998) When do environment-recruitment correlations work? Rev Fish Biol Fish 8:285-305

Myers RA, Barrowman NJ (1996) Is fish recruitment related to spawner abundance? Fish Bull (Wash DC) 94:707-724

Editorial responsibility: Otto Kinne (Editor),

Oldendorf/Luhe, Germany
NRC (National Research Council) (1994) An assessment of Atlantic bluefin tuna. National Academy Press, Washington, DC

Ólafsson J (1985) Recruitment of Icelandic haddock and cod in relation to variability in the physical environment. Int Counc Explor Sea Comm Meet 1985/G:59

Ricker WE (1954) Stock and recruitment. J Fish Res Board Can 11:559-623

Sæmundsson B (1924) Fiskarnir (Pisces Islandiae). Felgasprentsmidjan, Reykjavik

Schopka SA (1994) Fluctuations in the cod stock off Iceland during the twentieth century in relation to changes in the fisheries and environment. ICES Mar Sci Symp 198: 175-193

Sinclair M (1988) Marine populations. An essay on population regulation and speciation. Washington Sea Grant Program. University of Washington Press, Seattle, WA

Stephenson RL (1999) Stock complexity in fisheries management: a perspective of emerging issues related to population sub-units. Fish Res (Amst) 43:247-249

Swartzman G, Huang C, Kaluzny S (1992) Spatial analysis of Bering Sea groundfish survey data using generalized additive models. Can J Fish Aquat Sci 49:943-962

Trippel EA (1998) Egg size and viability and seasonal offspring production of young Atlantic cod. Trans Am Fish Soc 127:339-359

Submitted: September 1, 2000; Accepted: May 23, 2001 Proofs received from author(s): February 25, 2002 